УДК 539.234

\title{
Core-shell Nanosize Particles Mg@Ni: Synthesis and Properties
}

\author{
Grigory N. Churilov* \\ Nikita S. Nikolaev ${ }^{\dagger}$
}

Siberian Federal University, Svobodny, 79, Krasnoyarsk, 660041 Kirensky Institute of Physics, Federal Research Center KSC SB RAS

Akademgorodok, 50/38, Krasnoyarsk, 660036

Russia

Irina V. Osipova $a^{\ddagger}$

Kirensky Institute of Physics, Federal Research Center KSC SB RAS

Akademgorodok, 50/38, Krasnoyarsk, 660036

Russia

Alexander V. Cherepakhin ${ }^{\S}$

Siberian Federal University, Svobodny, 79, Krasnoyarsk, 660041 Kirensky Institute of Physics, Federal Research Center KSC SB RAS

Akademgorodok, 50/38, Krasnoyarsk, 660036

Russia

Ivan V. Nemtsev

Krasnoyarsk Scientific centre of SB RAS

Akademgorodok, 50, Krasnoyarsk, 660036, Russia

Dmitriy A. Velikanov"

Kirensky Institute of Physics, Federal Research Center KSC SB RAS

Akademgorodok, 50/38, Krasnoyarsk, 660036, Russia

Valentina G. Andyuseva**

Siberian Federal University, Svobodny, 79, Krasnoyarsk, 660041

Russia

Received 20.06.2018, received in revised form 23.10.2018, accepted 26.11.2018

In this paper, we study particles with metallic core (magnesium) - metal shell (nickel) structure, synthesized in metal-containing plasma of high frequency arc discharge. X-ray diffraction analysis, X-ray fluorescence analysis and scanning electron microscopy show that the particles have a uniform nickel shell, which is also indirectly confirmed by comparing the results of hydrogenation of $M g$ and $M g @ N i$ particles. Measurement of volume magnetization indicates that shell thickness of most particles is not more than 22 $\mathrm{nm}$.

Keywords: core-shell, nanopartials, nickel-magnesium, synthesis in plasma, surface coating. DOI: 10.17516/1997-1397-2019-12-1-28-35.

\footnotetext{
*churilov@iph.krasn.ru

†a6rukoc@yandex.ru

†osipova-iv@yandex.ru

$\S$ a.cherepakhin@ya.ru

『ivan_nemtsev@mail.ru

॥pona@krovatka.su

**vandyuseva@sfu-kras.ru

(C) Siberian Federal University. All rights reserved
} 


\section{Introduction}

In the early 1990s, researchers synthesized multilayer semiconductor nanoparticles to improve the characteristics of semiconductor materials. Subsequently, for such particles the name "particles with a core-shell structure" was adopted [1-2]. Catalysis, nonlinear optics, magnetic fluids, biotechnology, hydrogen energy, information storage and metamaterials are far from a complete list of areas of their possible application [3].

Most often, chemical, plasma-chemical and autoclave methods for the formation of shells on the surface of particles are used to produce powders with particles having a core-shell structure [4]. Also, methods of chemical vapor deposition andphysical vapor deposition were widely used [5]. The main disadvantages of the methods to form shells are the agglomeration of particles and the formation of shells consisting of smaller particles attached to the core material. In the first case, the particles are obtained in the form of clustersand in the second one, a so-called "island type" coating is formed. In this case, the particles are called "decorated". The shell of such particles is not uniform, totallycovering the core. Such particles are successfully appliedto solve some problems, e.g., catalysis [6]. However, there are a number of problems connected withthe protection of the core material from the environment [7]. On the other hand, if a core material and a uniform shell material had different Fermi energy, it would lead to a "super atom" type structure, which is promising from a fundamental point of view.

The most effective method to obtain particles with such a structureappears to be the method of metal condensation from plasma volume on the particle surface. The particles that play the role of a core are introduced into the plasma with an inert gas flow. In combination with rapid cooling, this makes it possible to prevent agglomeration of the particles and to ensure the formation of a uniform shell under core wetting with shell material condensed on the core. The flow of transport gas carries cold core particles introduced into plasma volume with the atoms of shell materials. These particles act as centers of condensation. To get surface diffusion of adsorbed atoms a working volume time of particles is needed to be obtained. To increase the conversion, the cross section of the plasma volume must be much greater than the surface through which the material to be coated enters his volume. The process of coating a low-melting material with high-melting material is a complex scientific and practical problem. To solve it, the authors used a two-step synthesis method in this work. The aim of this work was to create a uniform and all-solid shell of high-melting metal on the surface of a low-melting metal, namely a nickel shell on the surface of magnesium particles.

\section{Experimental section}

At the first step, using a high-frequency discharge $(55.6 \mathrm{kHz})$, a magnesium powder was synthesized in a water-cooled chamber. Magnesium in a graphite crucible was completely meltedunder the high frequency current, followed by a discharge applied to the surface of the melt. The magnesium vaporized by the arc discharge in the state of the powder condensed on the walls of the chamber [9].

Fig. 1 shows that most particles have distinct crystal faces. Statistical processing of microphotographs was carried out, and a diagram of size-dependantparticle distribution was made (Fig. 2). The particle size ranges 10-380 nm. Most particles in the powder are of the size 60-80 $\mathrm{nm}$. The average particle size is $95 \mathrm{~nm}$.

In the second step, the magnesium powder was introduced into a metal-containing plasma 


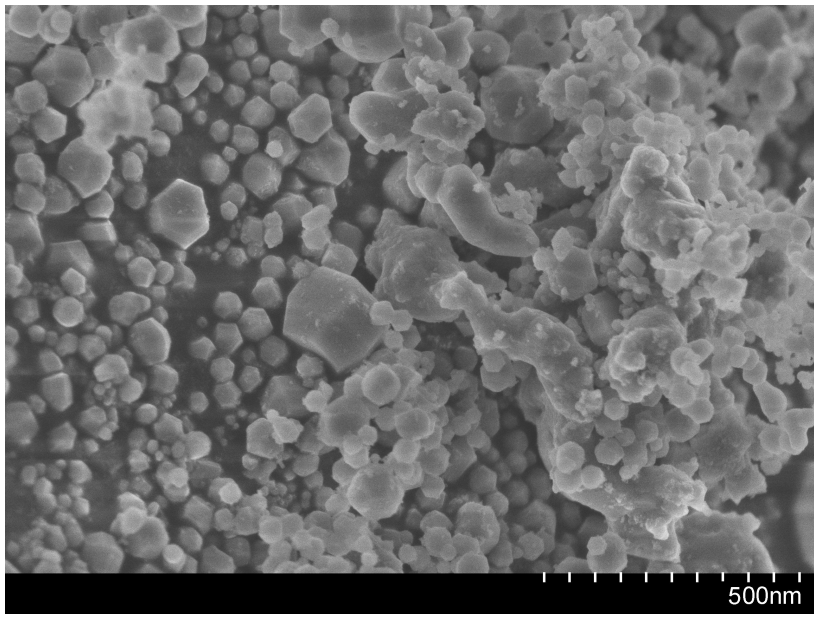

Fig. 1. Scanning electron microscopy image of magnesium powder. Powder synthesis at the first step

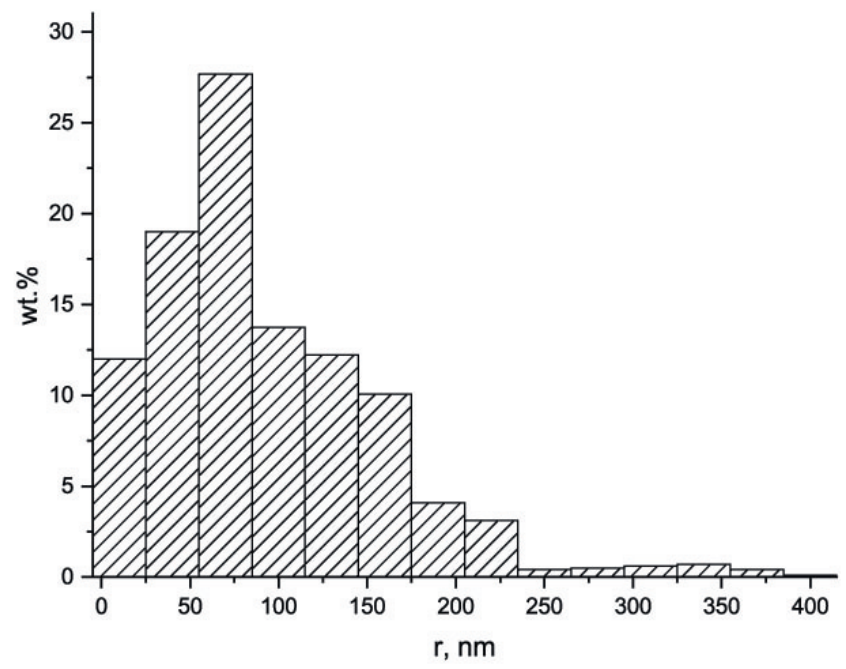

Fig. 2. Diagram of size-dependent magnesium powder particles

volume. The plasma was generated by a stabilized high-frequency nickel containing discharge in argon flow. [10]. Together with the flow of the plasma-forming gas (Ar) magnesium powder entered the discharge gap. Passing through a discharge gap saturated with nickel vapor, the magnesium particles acted as centers of condensation. The adsorbed atoms formed $\mathrm{Ni}$ films on the Mg surface. The powder with a core-shell particle structure condensed on the walls of the reaction chamber (Fig. 3).

After the second step of synthesis, particles of predominantly spherical shape were formed. The surface of the magnesium particles melted and the condensing nickel formed a spherical shell. A statistical analysis of microphotographs was performed to determine the size-dependant particle distribution (Fig. 4).

The distribution of particles size shows that most particles are of the size 170-200 nm. The average particle size is $190 \mathrm{~nm}$. Formedparticles aremostly in the size range10-420 nm. 


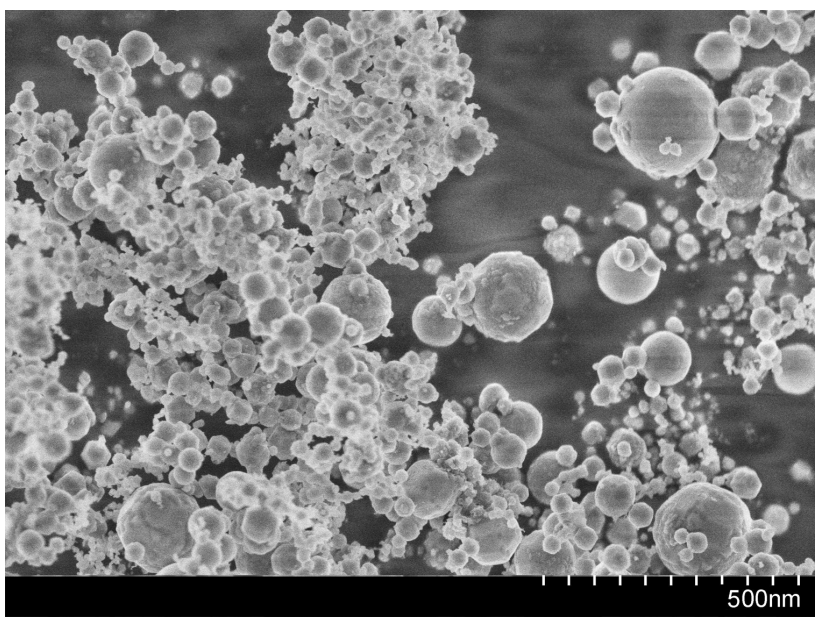

Fig. 3. Scanning electron microscopy image of nickel-coating magnesium powder. Powder synthesis at the second step

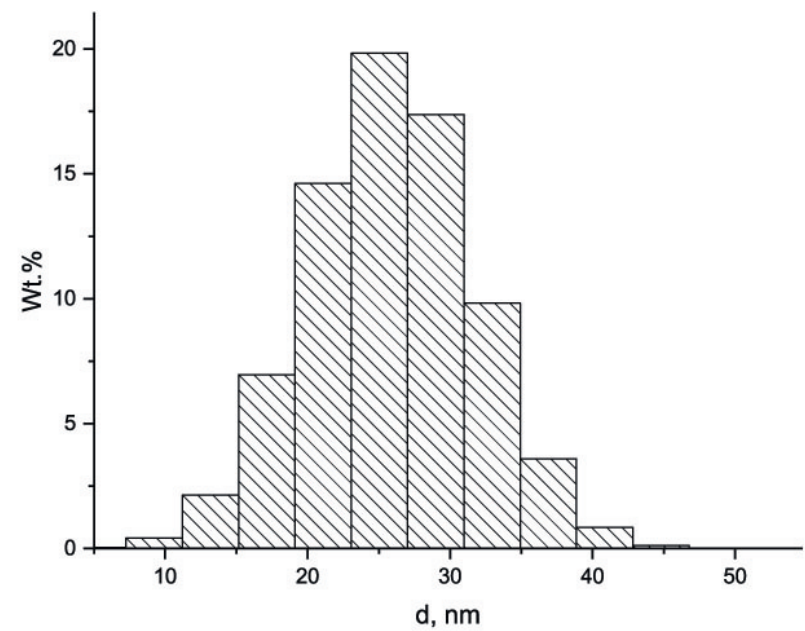

Fig. 4. Diagram of size-dependent powder with a core-shell particles structure

\section{Results and discussion}

The obtained samples were investigated by X-ray diffraction (XRD) (Fig. 5) and scanning electron microscopy (SEM)with energy dispersive X-ray spectroscopy (Fig. 6).

XRD method showsthatonce the magnesium powder is processedwith nickel containing plasma, phases of metallic nickel, magnesium oxideand insignificant amorphous component appear.

Surface element mapping by X-ray fluorescent microanalysis (Fig. 6) shows that nickel can be found on the surface of magnesium nanoparticles, thus forming a uniform film. In the sampleMg@Ni contains 6.7 wt.\% nickel. Particles are of a rounded shape as a result of fusion in the plasma arc discharge.

The magnetic properties of the obtained $\mathrm{Mg} @ \mathrm{Ni}$ powder were measured.

As shown by the measurements for the sample obtained, the saturation magnetization is 


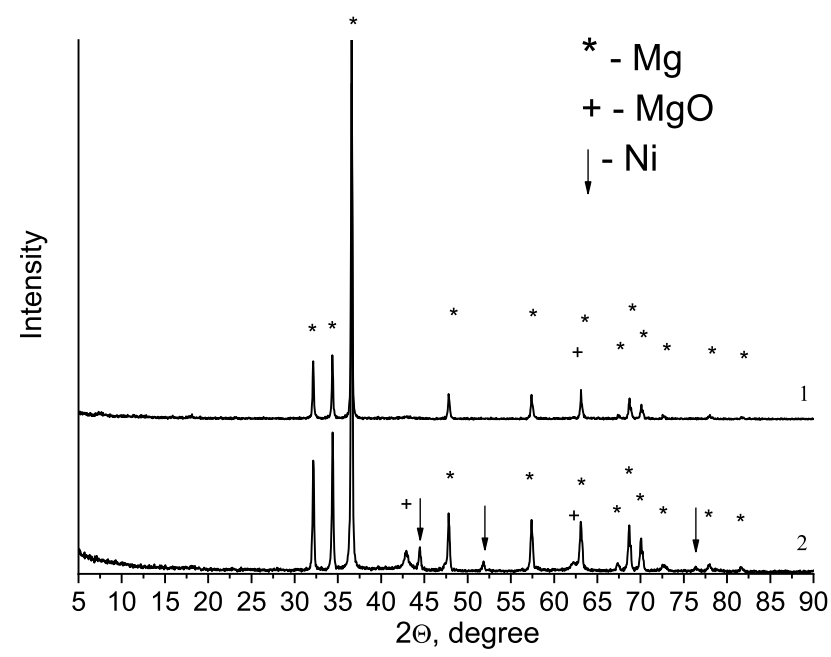

Fig. 5. XRD pattern of (1) sample after first step, and (2) sample after second step
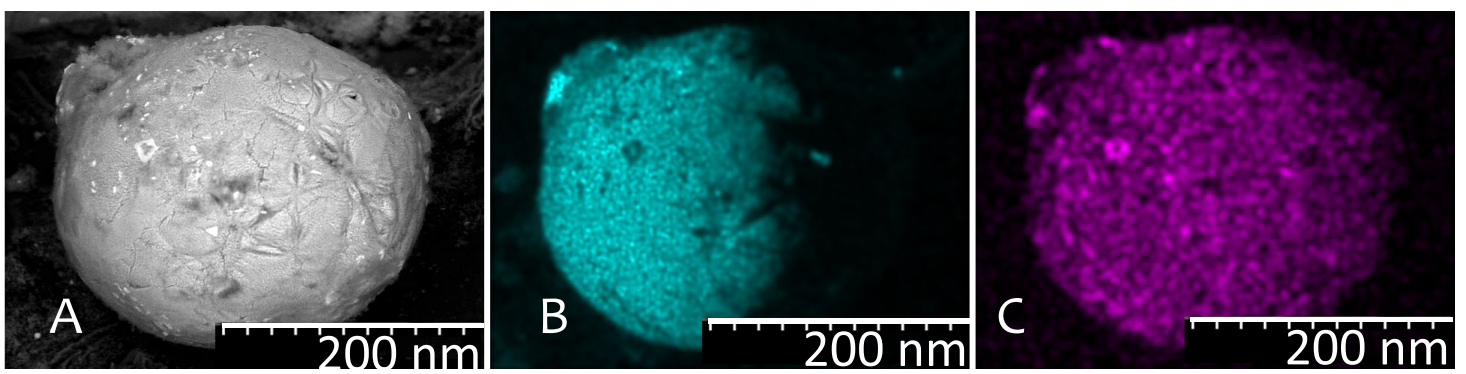

Fig. 6. (A) SEM image of $\mathrm{Mg} @ N i$ particle, (B) elemental mapping images of $\mathrm{Mg}$, (C) elemental mapping images of $\mathrm{Ni}$

$\mathrm{Ms}=0.42 \mathrm{emu} / \mathrm{g}$. In this case, the saturation field is $\mathrm{Hs}=1700 \mathrm{Oe}$, and the coercive force $\mathrm{Hc}$ is within zero (Fig. 7). The mass fraction of the magnetic phase can be estimated at the level of 0.76 wt. \%.

Nickel clusters are known to possess ferromagnetic properties in case their size exceeds $21.2 \mathrm{~nm}$ [11]. Nickel in the sample is only on the surface of magnesium particles, as shown by scanning electron microscopy. Consequently, for most particlesshell thickness does not exceed $20 \mathrm{~nm}$.

Powders of $\mathrm{Mg}$ and $\mathrm{Mg} @ \mathrm{Ni}$ were investigated in the hydrogenation/dehydrogenation process (Fig. 8). The hydrogenation was carried out at the temperature of $400^{\circ} \mathrm{C}$ and the pressure of 50 bars. The dehydrogenation was carried out at the temperature of $450^{\circ} \mathrm{C}$. The nanodispersed magnesium powder stores up to $5.6 \mathrm{wt} . \%$ of hydrogen. The same magnesium powder, but after being coated with the nickel shell stores an average of no more than $0.2 \mathrm{wt} . \%$ hydrogen. The XRS method does not reveal the magnesium hydride phasein the powder with $\mathrm{Mg} @ \mathrm{Ni}$ particles. It is known [12] that nickel membranes do not pass hydrogen at the temperatures below $1000^{\circ} \mathrm{C}$. Consequently, the magnesium in the synthesized particles is covered by a solid nickel shell. Nonzero value of sorption is related to the developed surface, which adsorbs hydrogen in a small amount. 


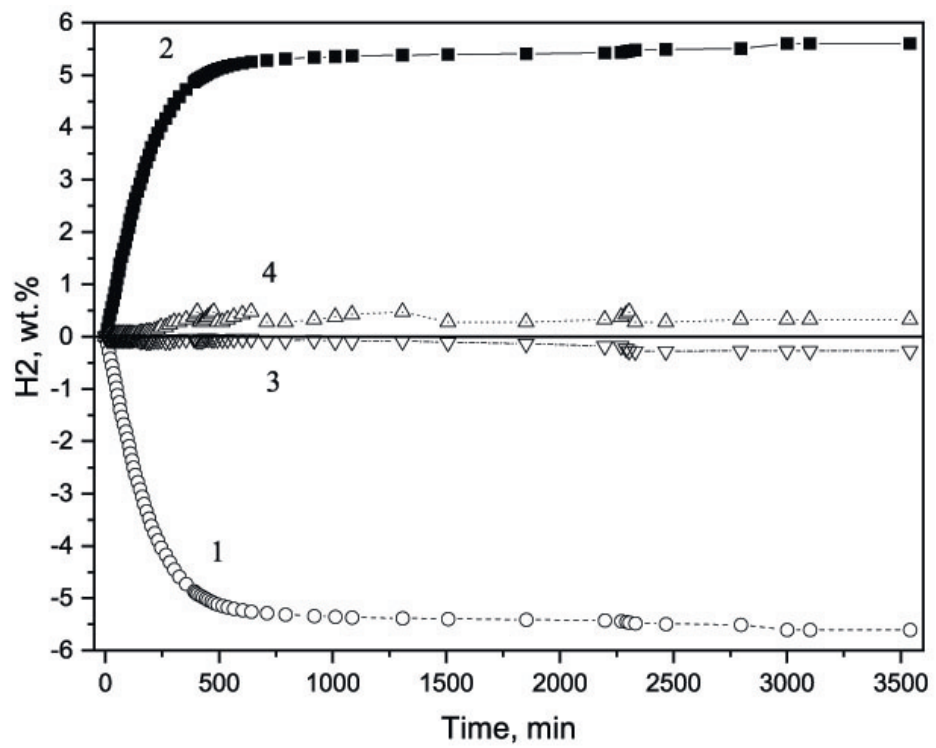

Fig. 7. Time-resolved $H_{2}$ wt.\% change during hydrogenation/dehydrogenation. (1) hydrogen absorption by magnesium powder, (2) hydrogen desorption by magnesium powder, (3) hydrogen absorption by $\mathrm{Mg} @ \mathrm{Ni}$ powder, (4) hydrogen desorptionby $\mathrm{Mg} @ \mathrm{Ni}$ powder

\section{$\mathrm{M}(\mathrm{emu} / \mathrm{g})$}

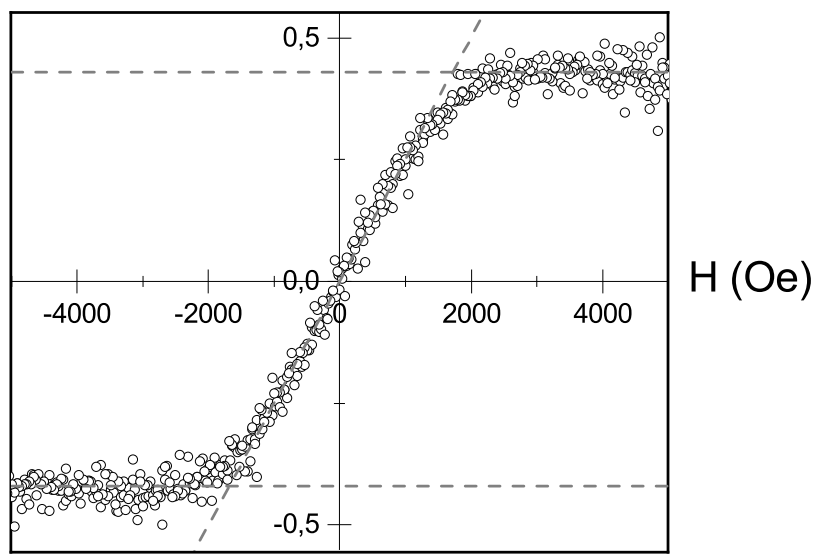

Fig. 8. The magnetization curve of powder Mg@Ni. The curve dimensions on the automated vibrating magnetometer with Puzey electromagnet at room temperature

\section{Conclusion}

Powder with the Mg@Ni particle structure is possible to be obtained by a two-step synthesis based on a high-frequency arc discharge. The $\mathrm{Mg}$ particles are ofpolycrystalline structure with an average size of $180 \mathrm{~nm}$ and are covered by a uniform $\mathrm{Ni}$ shell. According to the results of measuring the volume magnetization, it is shown that number of particles of shell thicknessmore than $22 \mathrm{~nm}$ is $0.76 \mathrm{wt} . \%$. The nickel shell of the particles does not allow the magnesium to form a hydride, which also proves that the nickel shell is uniform, without cracks 
To study the surface of the sample the research was carried out with a scanning electron microscope S-5500 in the Center of the common use of Krasnoyarsk Scientific Center, Siberian Branch of Russian Academy of Sciences.

\section{References}

[1] C.F.Hoener, K.A.Allan, A.J.Bard, A.Campion, M.A.Fox, T.E.Malluok, S.E.Webber, J.M.White, Demonstration of a shell-core structure in layered cadmium selenide-zinc selenide small particles by x-ray photoelectron and Auger spectroscopies, J. Phys. Chem., 96(1992), 3812-3817.

[2] I.Honma, T.Sano, H.Komiyama, Surface-enhanced Raman scattering (SERS) for semiconductor microcrystallites observed in silver-cadmium sulfide hybrid particles, J. Phys. Chem., 97(1993), 6692-6695.

[3] R.G.Chaudhuri, S.Paria, Core/Shell Nanoparticles: Classes, Properties, Synthesis Mechanisms, Characterization, and Applications, Chem. Rev., 112(2012), 2373-2433.

[4] J.F.Li, Y.J.Zhang, S.Y.Ding, R.Panneerselvam, Z.Q.Tian, Core-Shell Nanoparticle-Enhanced Raman Spectroscopy, Chem. Rev., 117(2017), 5002-5069.

[5] X.B.Meng, X.W.Wang, D.S.Geng, C.Ozgit-Akgun, N.Schneider, J.W.Elam, Atomic layer deposition for nanomaterial synthesis and functionalization in energy technology, Mater. Horiz., 4(2017), 133-154.

[6] Y.Liu, L.Chen, T.-M.Lu, G.-C.Wang, Low-temperature cycling of hydrogenation-dehydrogenation of Pd-decorated Mg nanoblades, Int. J. Hyd. Enegy, 36(2011), 11752-11759.

[7] M.C.Daniel, D.Astruc, Gold Nanoparticles: Assembly, Supramolecular Chemistry, Quantum-Size-Related Properties, and Applications toward Biology, Catalysis, and Nanotechnology, Chem. Rev., 104(2004), 293-346.

[8] S.A.Ivanov, J.Nanda, A.Piryatinski, M.Achermann, L.P.Balet, I.V.Bezel, P.O.Nikeeva, S.Tretiak, V.I.Klimov, Light Amplification Using Inverted Core/Shell Nanocrystals: Towards Lasing in the Single-Exciton Regime, J. Phys. Chem. B, 108(2004), 10625-10630.

[9] E.I.Melnikova, A.L.Kolonenko, G.A.Glushenko, N.G.Vnukova, G.N.Churilov, Nanodispersed Mg-based powders received in a hydrogen-argon plasma flow and estimation of their application prospects as hydrogen storage materials, Journal of Siberian Federal University. Mathematics \& Physics, 10(2017), 75-82.

[10] A.G.Sukovatyi, G.N.Churilov, S.S.Mal'tseva, High-Frequency Setup for the Emission Spectral Analysis and Smelting of Precious Metals, Instruments and Experimental Techniques, 5(1998), 719-722.

[11] K.V.P.M.Shafi, A.Gedanken, R.Prozorov, J.Balogh, SonochemicalPreparationand SizeDependent Properties of Nanostructured CoFe2O4 Particles, Chem. Mater., 10(1998), $3445-3450$.

[12] J.R.Davis, Nickel, Cobalt, and Their Alloys, ASM International, 2000. 


\section{Наночастицы Mg@Ni, их получение и свойства}

Григорий Н. Чурилов

Сибирский федеральный университет, Свободный, 79, Красноярск, 660041

Институт физики им. Л.В. Киренского ФИЦ КНЦ СО РАН

Академгородок, 50/38, Красноярск, 660036

Россия

Ирина В. Осипова

Институт физики им. Л.В. Киренского ФИЦ КНЦ СО РАН Академгородок, 50/38, Красноярск, 660036

Россия

Александр В. Черепахин

Сибирский федеральный университет, Свободный, 79, Красноярск, 660041

Институт физики им. Л.В. Киренского ФИЦ КНЦ СО РАН

Академгородок, 50/38, Красноярск, 660036

Россия

Иван В. Немцев

Красноярский научный центр СО РАН

Академгородок, 50, Красноярск, 660036

Россия

Дмитрий А. Великанов

Институт физики им. Л.В. Киренского ФИЦ КНЦ СО РАН

Академгородок, 50/38, Красноярск, 660036

Россия

Валентина Г. Андюсева

Сибирский федеральный университет, Свободный, 79, Красноярск, 660041

Россия

$\overline{B \text { данной работе исследованы частицы со структурой металлическое ядро (магний) - метал- }}$ лическая оболочка (никель), полученные в металлсодержащей высокочастотной плазме дугового разряда. Методами рентгенобазового анализа, рентгенофлуоресцентного анализа, сканирующей электронной микроскопии показано, что частицы имеют сплошную никелевую оболочку, что также косвенно подтверждается сравнением результатов гидрирования частии, $\mathrm{Mg}$ u $\mathrm{Mg} @ \mathrm{Ni}$. С помощъю измерений объемной намагниченности установлено, что наибольшая часть частии имеет толщину оболочек не более 22 нм.

Ключевые слова: частицы ядро-оболочка, наночастицы, никель-магниевые частицы, плазмохимический синтез, покрытие поверхности частицы. 